\title{
ANTI-ULCER ACTIVITY FROM THE LEAVES OF Bryophyllum sp.
}

ANDREA C. PEREZ; MARILAINE F. CORREA; SILVIA R. BORGES

Departament of Basic Sciences, School of Dentistry, UNESP, São Jose dos Campos, SP

\begin{abstract}
Anti-ulcer protective properties of an ethanol extract of Bryophyllum spp leaves were assayed in an animal model indomethacin induced gastric ulcer.
\end{abstract}

RESUMO - Foi estudado o efeito protetor anti-úlcera, por ingestão oral de um extrato etanólico de folhas de Bryophyllum spp, em modelo experimental de úlcera induzida por indometacina.

\section{Introduction}

Until recently, little was known about the chemistry of the plants of the Crassulae family, including Bryophyllum sp, for which previous phytochemical and pharmacological data have not been reported. Chemically, the species has been found to contain alkaloids, nitrates and soluble oxalates (WILLIAMS and SMITH, 1984).

A tea made up with the leaves of this species was found to be effective in relieving ulcer disorders (CORREA et al., 1998).

In order to understand the pharmacological bases for the use in folk medicine of Bryophyllum $s p$ for the treatment of ulcer illnesses, the present study was designed to investigate the effect of aqueous and ethanolic extracts obtained from these species on ulcer induced by indomethacin.

\section{Material and Methods}

Male Wistar rats weighting 200-250g were used. All animals were kept under controlled conditions at least one week prior to their use.

The extracts were administered $(0.5 \mathrm{ml}$, p.o.) daily for 1 week prior to ulcer induction.

The animals were deprived of food for $48 \mathrm{~h}$ and then given indomethacin orally at $30 \mathrm{mg} / \mathrm{kg}$. The animals were killed $20 \mathrm{~h}$ later and the stomach of each was examined for lesions developed in the glandular portion, as described in REITMAN, 1970.

\section{Results and Discussion}

The aqueous extract did not prevent the formation of the gastric mucosal lesions induced by indomethacin. On the other side the ethanol extract protected the stomach as shown on table 1 .

Table 1 Effect of Bryophyllum sp ethanol extract on indomethacin-induced gastric lesions in rats.

\begin{tabular}{l|c|c|c}
\hline \multicolumn{1}{c|}{ Treatment (p.o.) } & $\mathrm{n}$ & Lesion index & inhibition (\%) \\
\hline Control & 6 & 5.0 & 50 \\
Extract & 6 & $2.5 \pm 0.5 *$ & 5 \\
\hline
\end{tabular}

Results are expressed as mean \pm S.E.. $* p<0.05$

The plant is rich in alkaloids, nitrates and soluble oxalates present in nontoxic concentration (WILLIAMS and SMITH, 1984). The mean lethal doses were $5.0 \mathrm{~g}$ dry matter/Kg (Mc KENZIE and DUNSTER, 1986).

Bulfadienolides, a potent glycoside, have also been isolated from this specie and probably account for the observed disease in cattle, as the syndrome is consistent with cardiac glycoside poisoning ( $\mathrm{Mc}$

Address for correspondence: Prof. Andrea Perez - Departamento de Ciencias Básicas, Faculdade de Odontologia, UNESP - Av. Francisco Jose Longo 777 - São Jose dos Campos, SP - CEP 12245-000 - Tel (012) 3218166 R 1201 - e mail: andreaperez@zipmail.com.br.
KENZIE et al., 1987; MASVINGWE and MAVENYENGWA, 1997).

So far the studies have shown that this plant has a potential therapeutic effect. A few reports have demonstrated that is has ATPase activity (FISCHER-SCHLIEBS et al., 1997), chemotaxis (KEMNER et al., 1997) and therapeutic effect in murine leishmaniases (Da SILVA et al., 1995).

It is suggested that this protective effect is due to its hiposecretory activity, since the extract also inhibited salivary secretion (PEREZ, 1999).

The detailed mechanism of action and the principle(s) responsible for the anti-ulcer 
activity remains unclear and must await further study.

In summary it was apparent from the above results that the ethanol displays an exerted antiulcer effect in animal model of acute ulcer.

\section{REFERENCES}

CORREA, M. F., BORGES, S. R. and PEREZ, A. C. Efeito anti-ulcera da Folha Santa (Bryophyllum). Anais X Congresso de Iniciação Científica, p. 215, Araraquara, 1998.

Da SILVA, S. A., COSTA, S. S., MENDONÇA, S. C., SILVA, E. M., MORAES, V. L., ROSSIBERGMANN, B. Therapeutic effect of oral Kalanchoe pinnata leaf extract in murine leishmaniasis. Acta Trop. 60:201, 1995.

FISCHER-SCHLIEBS, E., BALL, E., BERNDT, E., BESEMFELDER-BUTZ, E., BINZEL, M. L., DROBNY, M., MUHLENHOFF, D. MULLER, M. L., RAKOWSKI, K., RATAJCZAK, R. Differential immunological cross-reactions with antisera against the V-ATPase of Kalanchoe daigremontiana reveal structural differences of V-ATPase subunits of different plant species. Biol. Chem. 378:1131, 1997.
KEMNER, J. M., LIANG, X. and NESTER, E. W. The agrobacterium tumefaciens virulence gene chvE is part of a putative ABC-type sugar transport operon. $J$. Bacteriol., 179:2452, 1997.

MASVINGWE, C. and MAVENYENGWA, M. Kalanchoe lanceolata poisoning in Brahman cattle in Zimbabwe: the first field outbreak. J. S. Afr. Vet. Assoc. 68:18, 1997.

McKENZIE, R. A., FRANKE, F. P. and DUNSTER, P. $\mathrm{J}$. The toxicity to cattle and bufadienolide content of six Bryophyllum species. Aust. Vet. J., 64:298, 1987.

McKENZIE, R.A., DUNSTER, P. J. Hearts and flowers: Bryophyllum poisoning of cattle. Aust. Vet. J., 63:222, 1986.

PEREZ, A. C. Effect of Bryophyllum $s p$ on salivary secretion of rats. Anais SBPqO, Aguas de São Pedro, 1999 (in press).

REITMAN, S. in Gradwohl's clinical laboratory methods and diagnosis, 7th edn., (Frankel, S., Sonnenwirth, A. C., eds.), pp. 1949-1958, C. V. Mosby, London, 1970.

WILLIAMS, M. C., SMITH, M. C. Toxicity of Kalanchoe spp to chicks. Am J. Vet. Res., 45:543, 1984. 